\title{
Microbial Based Culture Systems: For Sustainable Shrimp Production
}

\author{
Chethurajupalli Lavanya ${ }^{1^{*}}$, Tambireddy Neeraja ${ }^{1}$, \\ Suresh Kummari ${ }^{2}$ and Meshram Supradhnya Namdeo ${ }^{1}$
}
${ }^{1}$ College of Fishery Science, Sri Venkateswara Veterinary University, Muthukur, Nellore, Andhra Pradesh, India
${ }^{2}$ College of Fishery Science, P.V. Narasimha Rao Telangana Veterinary University, Pebbair, Telangana, India

*Corresponding author

\section{A B S T R A C T}

\section{Keywords}

Microbial floc, Periphyton, P.vannamei, Sustainable aquaculture

Article Info

Accepted:

15 December 2019 Available Online: 20 January 2020
Marine aquaculture is the fastest growing food producing sector with major contribution from carps in terms of volume and shrimp by value. Continuous development of aquaculture demands new alternative technologies to achieve sustainable production with low economic cost. The microbial based systems like biofloc technology (zero water exchange systems) and artificial substrate integrated (periphyton based) in normal culture systems represents the best methods of practice to get healthy shrimp production. The microbial based systems are eco-friendly aquaculture practices which can stimulate both heterotrophic or autotrophic groups of bacteria by maintaining carbon to nitrogen ratio $(\mathrm{C}: \mathrm{N})$ that can converts nitrogenous wastes into useful microbial biomass which can serve as natural food source for the cultured organisms. On other side, biofloc and periphyton helps in improving water quality by the removal of toxic nitrogenous substances from these systems. This technology is economically viable, eco-friendly, and socially acceptable.

\section{Introduction}

Aquaculture is the fastest growing food sector in the world, but today's industry utmost contest is to yield high quality animals at the economically viable cost. However, the existing intensive shrimp culture systems with more water replacements and feed wastage causing adverse environmental impacts like eutrophication, uncontrollable plankton growth and others (Martinez-Porchas and Martinez-Cordova 2012). Shrimp culture is completely successful but industry needs to develop new technologies that will enhance the value and environmental sustainability (Kuhn et al., 2010).

As an alternative to the existing intensive culture systems, biofloc technology (BFT) has been developed as an intensive rearing system 
to make shrimp farming less cost effective and to increase the nutrient utilization efficiency, provide bioflocs as additional feed, reduce water use and effluent discharges and improve biosecurity (Wasielesky et al., 2006). Bioflocs are heterogeneous mixture of bacteria, filamentous microalgae, protozoans, rotifers, worms and nonliving components. Bacterial growth increases when carbon source is added to the water with vigorous aeration at $\mathrm{C} / \mathrm{N}$ ratio of 15:1 (Chamberiain and Hopkins, 1994; De Schryver et al., 2008). Biofloc particles contain useful microbes like Bacillus sp., Lactobacillus sp. and Vibrio sp. (Anand et al., 2014, Kumar et al., 2015), bioactive compounds like carotenoids (Xu and Pan, 2013) and are known for probiotic (Crab, et al., 2010) and immunostimulant (Anguilera-Rivera et al., 2014) properties.

Microbial based culture systems are highly suited for shrimps because of its anatomical modifications that will permit them to eat up microbial flock material and assimilate microbial proteins, by that taking advantage of microbial biomass as a natural feed. Wasilesky et al., (2006) reported that the natural productivity in BFT system provides natural in-situ food sources to the culture organism and enhance growth and survival. It is documented that L. vannamei mostly feeds on detritus and benthos (Cordova and PenaMessina, 2005), consume microbial floc in biofloc systems ${ }^{[12]}$ and can be able to thrive well (Hargreaves, 2013). Growing this species under biofloc based system has shown to improve digestive enzyme activity, growth performances and survival (McInthos, 2000; Tacon et al., 2002; Buford et al., 2004; Xu and Pan, 2012).

The probiotic effect of microbial floc can act on the Vibrio sp. both internally and externally and some external parasites of shrimp (Panigrahi et al., 2014). The periodical addition of carbohydrates in the water is known to select for polyhydroxy alkanoates (PHA) mobilization of bacteria in the form of bioflocs which can generate poly- $\beta$ hydroxy butyrate (PHB), having antibiotic and immunomodulatory effects (Sinha et al., 2008) and on consumption of these flocs by shrimp, PHAs degrades in the gut and contribute to antibacterial properties (Defoirdt et al., 2007).

The microorganisms in the bioflocs and their cell metabolites can enhance innate immune system of shrimp and give protection against microbes (Smith et al., 2003; Vazquez et al., 2009). Panigrahi et al., (2007) suggested that bioflocs are having some immune associated genetic materials like prophenoloxidase (PO), $\mathrm{PO}$ activation enzymes and serine proteinase 1 thus implying immunomodulation in the shrimp. Kim et al.(2014) concluded that high total haemocyte count (THC) and PO activity in L. vannamei cultured in microbial based culture systems clearly showing significantly higher expression levels of proPO1, proPO2 and PPAE1 genes, which regulate the PO stimulation systems.

The use of artificial substrates is another technique to enhance shrimp yield. These substrates can give space for the growth of periphyton which contains heterogeneous groups of microorganisms which can act as natural food for the cultured organisms and maintained water quality (Langis et al., 1988; Ramesh et al., 1999; Thompson et al., 2002). Some of the widely using natural substrates are bamboo, paddy straw, wood, sugar bagasse (van Dam et al., 2002) and some artificial substrates like polyethylene and polypropylene screens, plastic bottles and certain commercial products (Aquamats ${ }^{\mathrm{TM}}$ ) have been used as in culture systems of fish (Azim et al., 2004) and shrimp (Huchette et al., 2000; Bratvold and Browdy, 2001; Richard et al., 2009; Zhang, 2011). The substrate-based culture methods are also 
known as periphyton-based culture systems and the periphyton on substrate is consists of heterogenous mixtures like algae, bacteria, fungi, protozoa, zooplankton, detritus and other invertebrates (Azim and Wahab, 2005). It can absorb nutrients such as ammonia and nitrite from water and maintained the dissolved oxygen (DO) and $\mathrm{pH}$ (Azim et al., 2002; Dodds, 2003; Bender et al., 2004; Schveitzer et al., 2013).

The main aim of this review is application of microbial based culture systems in shrimp culture for sustainable production. The above information is mainly focus on the use of complex mixture of microorganisms such as bacteria, filamentous microalgae, protozoans, rotifers, worms and nonliving components as a natural food for the shrimp. Diverse studies have been conducted in this field with successful and useful results in shrimp culture. In addition to that, this review also gives basic knowledge about biofloc system to the students, researchers and industry people.

\section{Suitability of BFT for Shrimp Culture}

The basic factors in selection of species to be reared in a biofloc systems are includes tolerance to high suspended solids of water, physiological adoptions that permit them to feed on microbial biomass and digest (Milstein et al., 2001; Crab et al., 2012; Hargreaves, 2013). In the wild, vannamei ingest vast classes of phytoplankton, debris, macrophytes, small molluscs, crustaceans and zooplankton (Senanan et al., 2009). A study by Kent et al., (2011), revealed the capability of L. vannamei juveniles to feed on microalgae, reared in algal culture flasks. Thus crustaceans like shrimp and prawns are suitable species for BFT systems since they are detritivorous and opportunistic feeders which feed on bacteria, fungi and other decomposed material (Milstein et al., 2001).
Coyle et al., (2010) and Perez-Fuentes et al., (2013) Shrimp prefer natural over commercial food as they feed continuously. Hargreaves (2013) specified that the cultured organisms like shrimps and tilapias have morphological modifications that permit them to feed on natural food i.e biofloc and can able to digest it. The ability of various species of shrimp and prawn to utilize biofloc, there by its positive effect on physiological functions and growth is well documented (Table 1).

\section{Nutritional Composition of Biofloc}

Bioflocs are the best nutritional resource, but it is depends on the type of systems, environments (Ju et al., 2008a; Hargreaves, 2013). Intrinsically, bioflocs are eating by the reared organisms and start a nutrient recycling process within an aquaculture system. The nutritional worth of bioflocs to cultured organisms is reliant on many agents for instance food selection, both the capability to consume and digest it (Hargreaves, 2006). Looking at nutritional quality of bioflocs as shrimp food, different studies have been done. Bioflloc contains adequate quantity of crude protein, essential lipids, carbohydrates and ash required for aqua feed (Crab et al., 2010; Ballester et al., 2010). Ballester et al., (2010) reported bifloc Contains $30.4 \%$ of crude protein. This is accordant with $25-50 \%$ said by Hargreaves (2013). However, Ekasari et al., (2014) presented 17.2-27.8\% protein for biofloc harvested from shrimp culture systems, with Crab et al., (2010) In the bacteriological food web, essential lipids and poly unsaturated fatty acids (PUFA) are mostly released from flagellated and ciliated protozoans groups and other cyanophyta (Zhukova and Kharlamenko, 1999), although majority of microbes are insufficient sources for PUFA (Meyers and Latscha, 1997). Crab et al., (2010) reported that palmitic acids, palmitoleic acids and linoleic acids are the major group of fatty acids in biofloc. 
In biofloc the fatty acid profiles may vary based on the carbon sources employed, the type of water used (fresh water, sea water) and the methods of production suggested by Emerenciano et al., (2013). They also reported the presence of essential fatty acids such as linoleic acids, linolenic acids and arachidonic acids etc., in biofloc. In biofloc 6$7.5 \%$ of lipid content is found by by Ekasari et al., (2014) and it was within optimum range of $0.5-15 \%$ said by Hargreaves (2013). The major variations in nutritional properties of microbial biomass occur due to differences floc development (Rittmann and Mc Carty, 2001). For instance, bacteria could not develop on acetate and glycerol substrates but those can release huge amounts of exopolysaccharides, but are utilized by cultures organisms mostly spend for cell growth which can enhance the protein percentage in microbial biomass (Crab et al., 2010). These studies reported that nutritional value of bioflocs depends on the Carbon : Nitrogen ratio and nature of substrates etc. Hence, the fundamental element for the development of biofloc is choice of carbohydrate source. Proximate compositions of microbial biomass in different studies are shown in Table. 2

\section{Microbial Community in Biofloc}

Biofloc development in outside system is very much profit oriented because of production of photoautotrophs during day time with light (Ray et al., 2009; Avnimelech, 2012; Baloi et al., 2013). and water colour may change from a green algal type to a brown bacterial type by increasing feeding rate, and calculated for microbial groups as colour index (Hargreaves, 2013). This colour change is one of the most important methods for reduction of ammonia to microbial groups, which can also demand more aeration (Hargreaves, 2013). The beneficial bacteria in the BFT are providing a natural food and maintain quality of water
(Avnimelech, 2012). In BFT, chemoautotrophic nitrifying bacteria, and heterotrophic ammonia assimilating bacteria are two important bacterial groups to maintain water quality (Ebeling et al., 2006; Ray et al., 2010a), with the actions high oxygen demand and low level of alkalinity, which needs more DO supply (Ray et al., 2010a).

The pathway of nitrifying bacteria in culture system has been widely studied (Tal et al., 2003; Michaud et al., 2006; Crab et al., 2007). The main principle is conversion of total ammonia nitrogen to nitrites and nitrite is converted into nitrate which is less toxic to fish (Peng and Zhu, 2006; Ray et al., 2010b; Hargreaves, 2013) and simultaneously the removed TAN may developed it into cellular protein and it is providing natural food for rearing animals (Ebeling et al., 2006; Ray et al., 2010a). In addition to that, the rate of growth of heterotrophic bacteria is ten times more than nitrifying bacteria when sufficient organic carbon supplied, which may results in reduction of TAN levels and increment of microbial community and nutritional quality $[63,12,13]$. Some studies have been carried out on microbial community structure and composition of bioflocs in shrimp culture (Hargreaves, 2006; Crab et al., 2012; Hargreaves, 2013). Some studies have been carried out on microbial community structure and composition of bioflocs in shrimp culture (Ju et al., 2008a; Ballester et al., 2010; Anand et al., 2014; Ekasari et al., 2014; Kumar et al., 2015). According to $\mathrm{Ju}$ et al., (2008) microbial biomass from L. vannamei cultured tanks having $24.6 \%$ of phytoplankton (dominated by diatoms like Thalassiosira, Chaetoceros and Navicula), 3\% bacterial groups (two-third was G-ve and one-third of $\mathrm{G}+\mathrm{ve})$, a small quantity of protozoans (98\% flagellates, $1.5 \%$ rotifers and $0.5 \%$ amoebae), $33.2 \%$ of dead material and the remaining ash $(39.25 \%)$. It indicates that microbial biomass having heterogenous groups organisms. 
Biofloc from $F$. paulensis cultured tanks were consists of heterotrophic bacteria, cyanobacteria, dinoflagellates, ciliates, flagellates and rotifers (Ballester et al., 2010).

Anand et al., (2014) The dominant microbial groups are Vibrio sps, Lactobacillus sps, Bacillus sps and fungi in biflocs. However, Vibrio sps. and Bacillus sps. dominated over Lactobacillus sps. The probiotic bacteria such as Bacillus sps. and Lactobacillus sps. in their gastrointestinal tract (GIT) of L. vannamei can leads to enhance digestive enzyme activity and immune response (Xu and Pan, 2013). The digestive enzyme secretions from Bacillus and Lactobacillus in the carbon addition systems shows better growth rate (Ringo et al., 2012; Anand et al., 2014). The microbial biomass in BFT can increase the digestive and assimilative capacity of shrimp resulted in best growth rate and survival (Anand et al., 2014). In another study by Ekasari et al., (2014) revealed revealed significantly lower $(\mathrm{P}<0.05)$ total viable bacteria count (TBC) in the waters of conventional semi intensive system over the biofloc system. Kumar et al., (2015) reported that molasses added treatment tank with highest level of TBC and Vibrio count than non-biofloc system.

\section{Microbial role in stimulation of digestive enzyme activity}

The microbial biomass in BFT plays a major role in stimulation of digestive enzymes activities in shrimps (Moss et al., 2001; Xu et al., 2012a) which could increase the growth rate of shrimp (Anand et al., 2014). Xu and Pan (2012) The increment of protease and amylase enzyme activities in $L$. vannamei reared in BFT systems. The beneficial bacterial groups such as Bacillus sps. in the biofloc helps to modify the physiological and immunological status of the animal, by colonization of bacterial in the GIT (Zhao et al., 2012; Xu and Pan, 2013). Studies in similar lines has shown increased level of digestive enzymes activity in fish and shrimp fed with probiotics, microalgae and periphyton supplemented diets (Lara-Flores et al., 2003; Ziaei-Nejad et al., 2006; Anand et al., 2014). In shrimps microbial flocs shows positive effect towards the enzyme activity which can accelerate feed digestibility and utilization suggested by Xu and Pan (2014). The feeding of microbial floc at $4 \%$ and $8 \%$ level to the prawns, it can increase the growth performance and digestive enzyme activity of like amylase, cellulose and protease in BFT systems compared with control reported by (Anand et al., 2014).

\section{Microbial role in water quality maintenance}

Microbial floc is another technology for keeping better water quality by the in situ action of living bacteria in the water, dominantly by heterotrophic group of bacteria (Avnimelech 1999 \& 2012; Hargreaves, 2013). The supplementation of tapioca into $P$. monodon culture system can reduce the total ammonium nitrogen and $\mathrm{NO}_{2}-\mathrm{N}$ concentrations reported by Hari et al., (2004 $\&$ 2006). The addition of tapioca in $M$. rosenbergii culture systems significantly decreases the TAN and $\mathrm{NO}_{2}-\mathrm{N}$ concentrations reported by Asaduzzaman et al., (2008). Ray et al., (2011) measured water temperature, $\mathrm{DO}, \mathrm{pH}$ and salinity twice per day and TAN, nitrite and nitrate once a week in L. vannamei culture systems with two levels of biofloc viz., low biofloc level (T-LS) and high biofloc level (T-HS) has shown higher TAN, $\mathrm{NO}_{2}$ and lower $\mathrm{NO}_{3}$ levels in T- LS than that of THS treatment. Raj Kumar et al., (2015) studied in three different biofloc systems viz., molasses, tapioca and wheat on the water quality, microbial floc composition and growth in L. vannamei revealed significantly less nitrogen species level in biofloc systems 
than that of control system without biofloc. Luis-Villaseñor et al., (2015) recorded water temperature, $\mathrm{DO}, \mathrm{pH}$, salinity twice daily and TAN, nitrite and nitrate at weekly intervals in L. vannamei culture showed significantly lower TAN, nitrite and nitrate levels in BFT system than control system. However, Effendy et al., (2016) observed significantly higher $(\mathrm{P}<0.01)$ values of $\mathrm{NO}_{2}$ and $\mathrm{NO}_{3}$ in semi biofloc system in comparison with semi intensive culture system of Fenneropenaeus indicus. Manan et al., (2017) also conducted experiment on bioremediation process in biofloc technology of P.monodon and concluded that the microorganisms in biofloc act as natural bioremediation agents ensure that they can maintain optimum water quality for shrimp.

\section{Microbial role in enhancement of growth in shrimp}

The growth efficiency is the foremost important to the aqua farmers throughout the world. The benefits of biofloc towards growth and survival of shrimp has been reported by Hari et al., (2004), Wisielesky et al., (2006), De Schrvey et al., (2008), Avnimelech and Kochba (2009), Krummenaeuer et al., (2011), Xu and Pan (2012), Kim et al., (2014), Kumar et al., (2015), Luis-Villasenor et al., (2015) and Effendy et al., (2016). Shrimp are mostly detritus feeders (Focken et al., 1998) that feeds on bacteria, fungi and decomposing material (Milstein et al., 2001; Serfling, 2006), thus capable of utilizing biofloc as food. The biofloc can elevate the rate of nutrient ingestion, absorption, assimilation and it can give a source of cellular nutrition in vannamei sps. (Tacon et al., 2002). The shrimp or fish has so many benefits by feeding on biofloc such as supply of various nutrients by the microbial community, increasing feed utilization and growth, stimulating digestive enzyme activities, lowering FCR and enhancing immune system (Burford et al., 2004; Moss et al., 2006;
Wasielesky et al., 2006; Ballester et al., 2010; Jang et al., 2011; Emerciano et al., 2012; Xu and Pan, 2012; Perez-Fuentes et al., 2013).

$\mathrm{Xu}$ and Pan (2012) reported more survival rate and better growth of vannamei in the BFT system with carbohydrate addition. Hargreaves (2013) reported that 20-30\% of shrimp growth in biofloc based culture system is obtained from microbial proteins in the water. The rate of assimilation of protein and lipid in biofloc treatments showed a positive contribution of biofloc prodeced from waste material as a natural feed for the cultured organisms with lower FCR in the BFT systems (Megahed et al., 2010; Zhao et al., 2012; Xu et al., 2012; Gao et al., 2012). Xu et $a l$. , (2012) reported that BFT-30\% and BFT$35 \%$ crude protein (CP) feed tank with significantly higher weight gain and SGR in $L$. vannamei juveniles when compared to control (clear water and 35\% CP feed) and no significant difference $(\mathrm{P}<0.05)$ among BFT25\%, BFT-30\% and BFT-35\%. Anand et al., (2014) evaluated the effect of biofloc under two carbohydrate sources (rice flour-R and molasses-M) and two levels protein diets (32\% and $40 \%$ ) in P. monodon juveniles has shown better $(\mathrm{P}<0.01)$ growth rate in $(40+$ $\mathrm{R}),(40+\mathrm{M})$ and $(32+\mathrm{R})$ treatments than control groups (32\% and $40 \%$ protein diets without biofloc). Kumar et al., (2015) found significantly higher $(\mathrm{P}<0.05)$ weight gain and protein conversion rate in L. vannamei fed on $35 \%$ protein diet in biofloc systems with cornmeal as carbohydrate source than the control shrimp without biofloc. Effendy et al., (2016) observed significant increase ( $\mathrm{P}$ $<0.01)$ in growth of Fenneropenaeus indicus fed with $35 \%$ protein feed in biofloc systems when compared to clear water system.

\section{Biofloc for shrimp Health Management}

The presence of microbial biomass in culture system had been reported to enhance the health of the cultivated organism which may 
be due to the inhibition of pathogens reported by Bricknell and Dalmo (2005). Bioflocs is a new technology for disease management with pobiotic effect in contrast to conventional materials like antibiotic, antifungal, external probiotic and prebiotic supplementation (Emerenciano et al., 2013). Further, bioflocs are reported to harbor huge microbes and bioactive compounds that shows positive effect on health of the shrimp (Xu and Pan, 2013).

Biofloc is also having amino sugars like glucosamine, muramic acid, bromophenols, phytosterols and pigments like carotenoids, chlorophylls and xanthophylls ( $\mathrm{Ju}$ et al., 2008a) they can elevate shrimp immune status by stimulating immune system (LinanCabello et al., 2002; Burford et al., 2004). In BFT system by regular supplementation of carbohydrate can enhance the growth of polyhydroxyalkanoate (PHA) aggregating microorganisms (Salehizadeh and Shojaosadati, 2001). Bacteria and the synthesized compounds might act as effective bio-control agents while providing the host with beneficial microbial balance in the gut (Emerenciano et al., 2013).

\section{Immunological response of shrimp in biofloc system}

The crustacean having a nonspecific immune system with phagocytic and humoral contents, as a foremost defense (Lee and Soderhall, 2001). The common immunostimulants like peptide, lipopolysaccharides, probiotics, microalgae, carotenoids, vitamins and peptides (Devaraja et al., 1998; Ringo et al., 2012). They can elevate immunity power in shrimps and enhance capacity to eject pathogenic bacteria (Flegel, 1997; Nonwachai et al., 2010). Ju et al., (2008a,b) and Anguilera-Rivera et al., (2014) suggested that the microbial flocs can confer benefits to the shrimp immune system which may be due to the presence of carotenoids, retinoids, poly- $\beta$ hydroxybutyrate and exo-enzymes. Microorganisms has been used as immunestimulants to enhance immune system and/or antioxidant status of shrimp, followed by increasing their resistance towards pathogenic bacteria (Ninawe and Selvin, 2009; Smith et al., 2003; Becerra-Dorame, 2012). It has been reported that Acute Hepatopancreatic Necrosis Syndrome (AHPNS) an raising disease outbreak with heavy mortality rate in shrimp culture appeared to have lower incidence at BFT systems (NACA, 2012) which suggest that biofloc can have positive impact on immune-response of shrimp.

In shrimps, three different haemocytes, viz., a granulocytes, granular and semi-granular haemocytes (SGH) has documented (Rodriguez and Le Moullac, 2000). The haemocytes perform different activities like phagocytosis, encapsulation, nodular aggregation (Soderhall and Cerenius, 1992; Vargas-Albores et al., 1998) and production of Propo enzymes (Lopez et al., 1996). In shrimp defence system granular cells plays an important role by their antimicrobial response (Chisholm and Smith, 1995) similarly a granulocytes act as a phagocytes, and involved in the production of agglutinins and antibacterial peptides (Rodriguez and Le Moullac, 2000).

The importance of total haemocyte count (THC) in disease resistance of shrimp has been documented (Rodriguez and Le Moullac, 2000; Ji et al., 2009; Xu and Pan, 2013). Rodriguez and Le Moullac (2000) reported that low THC value in L. stylirostirs became very sensitive to virulent Vibrio alginolyticus. In penaeids, THC from 20 - 40 x $10^{6}$ cells $\mathrm{ml}^{-1}$ of haemolymph (Chang et al., 1999). An increased levels of haemocyte count has been recorded after feeding shrimp with feed supplements such as probiotics (Rengpipat et al., 2000), $\beta$-glucan (Lopez et 
al., 2003), macroalgae and $\beta$-carotene supplemented diets (Supamattaya et al., 2005). The microorganisms of biofloc ingested by the shrimp may release substances in the gastrointestinal tract that could potently stimulate the innate immunity and release more haemocytes into the circulation (NACA, 2012).

$\mathrm{Xu}$ and Pan (2013) significantly higher THC and phagocytic activity of the haemocytes in vannamei cultured in BFT cultures than control. The vannamei cultured in microbial floc tank with addition of $20 \%$ to $35 \%$ protein levels showed that there is no differences in total haemocyte count and immune status between treatment tanks showing that there is no effect by decreasing the protein level in the biofloc tanks (Xu and Pan, 2014). Ekasari et al., (2014) found no significant difference in THC of vannamei shrimp rearing in biofloc tanks using various carbon sources. However, THC of vannamei from biofloc system having high values than control. Toledo et al., (2014) also reported no significance difference in THC of L. vannamei juveniles fed on diets with three different dietary lipids grown in molasses based biofloc systems. Significantly higher THC, granulocytes and hyaline cells count was observed in haemolymph of $P$. monodon juveniles grown in rice flour based biofloc system compared to controls with no biofloc (kumar et al., 2015). F. indicus juveniles grown in bifloc ponds have shown higher $(\mathrm{P}<0.01)$ THC in haemolymph than that of without biofloc shrimp before and after cold challenge test (Effendy et al., 2016).

In crustaceans, haemolymph components like protein, albumin, glucose, triglycerides and cholesterol levels reflects the nutritional quality of shrimp and it is high in shrimp fed on natural food (Gong et al., 2000) or as a outcome of stress (Hall and Ham 1998; LaraFlores et al., 2007). In serum protein of shrimps around $90-95 \%$ of haemocyanin is present (Depledge and Bjeregaard, 1989) and therefore its reduction can possibly affect specific immune proteins of that animal (Perazzolo et al., 2002). The serum total protein concentration in tiger shrimp was reported to decreased after exposing to the higher level of nitrite nitrogen (Chen and Cheng, 1995).

An experimental study by Anand (2012) revealed significantly higher $(\mathrm{P}<0.05)$ levels of serum protein in $P$. monodon juveniles fed on biofloc incorporated diets when compared the feed without biofloc component. Kumar et al., (2015) reported significantly higher $(\mathrm{P}<$ $0.01)$ serum protein levels in monodon juveniles cultured in microbial floc systems than that of conventional system. Both semigranular and granular cells are active in the proPO activity, which has a role in identification and defense in crustaceans (Rodriguez and Le Moullac, 2000; Chiu et al., 2007). Phenoloxidase is an enzyme of the crustaceans that leads to melanisation of foreign cells to inactivate and supress their multiplication in the host. Phenoloxidase is mostly produced by cell wall of bacteria such as $\beta$-1,3-glucans and lipopolysaccharides (LPS) (Perazzolo and Barracco, 1997; Sritunyalucksana and Soderhall (2000); Cerenius and Soderhall, 2012). Shrimps are consuming biofloc as a natural food in BFT systems (Crab et al., 2012; Ekasari et al., 2014) that increases in THC and PO activity which was confirmed in vannamei biofloc systems by Kim et al., (2014) clearly showing significantly higher levels of proPO1, proPO2 and PPAE1 genes, which regulate the proPO activation systems. Higher PO activity in $L$. vannamei grown in the biofloc systems was also observed during both pre and post challenging test by injection with infectious myonecrosis virus (IMNV) than that of shrimp from the non-biofloc control system (Ekasari et al., 2014). Kumar et al., (2015) reported higher $(\mathrm{P}<0.05)$ serum 
phenoloxidase activity in monodon juveniles reared in BFT system than control system.

In crustaceans, lysozymes are the primary defenders against pathogens (Vazquez et al., 2009). The invertebrate (i-lyz) lysozyme attacks both Gram-positive bacteria (Vocadlo et al., 2001) and G-ve bacteria (PeregrinoUriarte et al., 2012). The c-lyz (like hen egg white lysozyme) has been defined in various crustaceans like L. vannamei (Mundo et al., 2003), P. Japonicas (Hikima et al., 2003), P. chinensis ( $\mathrm{Bu}$ et al., 2008), P. monodon (Supungul et al., 2002; Tyagi et al., 2007), F. merguiensis (Mai and $\mathrm{Hu} 2009$ ) and $L$. stylirostris (Lorgeril et al., 2005; Mai and $\mathrm{Hu}$, 2009). Vega et al., (2006) reported antibacterial activity of $c$-lyz from $L$. vannamei against $V$. alginolyticus, $V$. parahemolyticus and $V$. cholerae. Chen et al., (2015 reported decreased lysozyme activity in vannamei that dipped in seawater having 600 ppm Gracilaria tenuistipitata extract after 72 hrs of post ammonia (5 ppm) stress while in control the lysozyme activity significantly decreased $(\mathrm{P}<0.05)$ after 24 hrs of exposure to $5 \mathrm{ppm}$ of ammonia itself. Therefore, vannamei that received Gracilaria tenuistipitata extract showed slow decreased and fast recovery in lysozyme activity than to their actual values showing a positive immune response of lysozyme against ammonia stress.

\section{Biofloc production and maintenance}

Bioflocs are defined as aggregates (flocs) of algae, phytoplankton, free and attached bacteria, grazers of bacteria such as ciliates, flagellates, rotifers, nematods and copepods, living and dead material such as faeces and uneaten feed (Hargreaves, 2006; Crab et al., 2009; Ray et al., 2010b; Ballester et al., 2010; Hargeaves 2013), yeast, cyanobacteria (Becerra-Dorame, 2012), colloids, organic polymers, cations and dead cells (De Schryver et al., 2008) and inorganic particies (Burford et al., 2003). Usual bioflocs are in unevenly manner, have a variety of distribution of particle size, are fine, easily compressible, and highly porous and are permeable to fluids (Chu and Lee, 2004). The development of biofloc in a new rearing culture tank requires inoculum such as soil or high microbial floc water from a previous production system (Gaona et al., 2011). Avnimelech (1999) reported using of $20 \mathrm{~g}$ clay soil, $10 \mathrm{mg}$ Ammonium Sulphate [(NH4)2SO4] and 200 mg glucose (carbohydrate source) shaken for $12 \mathrm{~h}$ with $1 \mathrm{~L}$ tap-water for the initial production of bioflocs. Similarly used $20 \mathrm{~g}$ of pond bottom soil in 1L of well aerated water containing $10 \mathrm{mg}$ of (NH4)2SO4 and $400 \mathrm{mg}$ of different carbon sources viz., tapioca, wheat, corn and sugar bagasse and were incubated for $24 \mathrm{~h}$ for initial floc development.

The main factor for the formation of microbial flocs is the capability of microbial cells to form microbial aggregates and quorum sensing property (De Schryver et al., 2008). Another contributing factors are Carbon:Nitrogen ratio, type of carbon source and inorganic nitrogen, aeration, $\mathrm{pH}$, temperature etc. The $\mathrm{C}: \mathrm{N}$ ratio plays an important role in BFT systems (Hargreaves, 2013), ], and is an essential factor in development of inorganic nitrogen to microbial cells (Avnimelech, 1999; McIntosh, 2000; Hargreaves, 2013). The conversion rate of heterotrophic bacteria in general is 40$60 \%$, carbon:nitrogen ratio of 10 or more in food is required for the growth of heterotrophic bacteria (Avnimelech, 1999). By increasing the $\mathrm{C}: \mathrm{N}$ ratio, the heterotrophic bacteria can absorb ammonia from the water and converted into microbial biomass, containing protein (Hargreaves, 2013). Fontenot et al., (2007) used four $\mathrm{C}: \mathrm{N}$ ratios $(5: 1,10: 1,20: 1$ and 30:1) in shrimp cultures by supplying molasses, and concluded that the $\mathrm{C}: \mathrm{N}$ ratio of $10: 1$ gave the better results in 
terms of high level of inorganic nitrogen removal from water. However, Luo et al., (2014) reported that $\mathrm{C}: \mathrm{N}$ ratio should be > 10:1. Hargreaves (2013) reported that $C: N$ ratio 12-15:1 will support the heterotrophic bacteria. Further ${ }^{[67]}$ reported with optimal ratio of $\mathrm{C}: \mathrm{N}$ from $15-20: 1$.

In In the case of high TAN levels Avnimelech (2012) suggested to apply $20 \mathrm{ppm}$ of organic carbon to decrease TAN level by $1 \mathrm{mg} / \mathrm{l}$. The supplementation of organic carbon in biofloc systems is very close to the feeding rate and protein content, or nitrogen content of the diet (Hargreaves, 2013). He reported that for every one kilogram of feed $30-38 \%$ protein added to the water, $0.5-1 \mathrm{~kg}$ of carbohydrate should be supply to keep high $\mathrm{C}: \mathrm{N}$ ratio.

Inorganic nitrogen and carbohydrate addition are primary materials for huge production of heterotrophic bacteria in BFT systems (Avnimelech, 1999; Ebeling et al., 2006). Heterotrophic bacteria utilize inorganic nitrogen produced from feed, excretions or fertilizers (Ammonium Sulphate). The carbohydrate acts as a substrate for processing BFT and development of microbial floc (Avnimelech, 1999). Even though, selection of carbon source depends on its cost, easy availability, biodegradability and efficiency of bacterial assimilation. Various types of carbon sources used with different cultured species in BFT systems are presented in table.3.

The organic carbohydrate supplementaion is related to the feeding rate and is generally added to water once, or twice in a day, after feeding (Avnimelech, 1999; Azim and Little, 2008; Xu et al., 2012). Wheat powder was used as carbon because of its easy accessible and making of best quality microbial floc (Azim and little, 2008; Ballester et al., 2010; Anand et al., 2014; Raj Kumar et al., 2015). Anand et al., (2014) used $4.03 \mathrm{Kg}$ of wheat flour to develop $1 \mathrm{~kg}$ of floc. Earlier, Kuhn et al., (2009) reported $1 \mathrm{~kg}$ microbial flocs production from $1.5 \mathrm{~kg}$ of sucrose in a bioreactor.

Raj Kumar et al., (2015) reported that the addition of wheat flour could helps to develop microbial floc and maintain water quality and increase shrimp yield over molasses, tapioca flour biofloc systems. Similarly, Anusha (2017) observed best floc composition in wheat flour produced biofloc when compared to tapioca, rice flour and molasses as carbon sources.

\section{Suitability of Substrate based Biofloc Technology for Shrimp Culture}

The artificial substrates are new methods employed in the growth of aquatic animals to elevate efficiency in rearing systems (Schveitzer et al., 2013). Artificial substrates like polyethylene and polypropylene sheets, plastic bottles, nets and other materials (Aquamats $^{\mathrm{TM}}$, Meridian, Calverton, MD, USA) have been produced and using under different culturing conditions, and reports of these experiments showing that these substrates can significantly increase the yield and survival of shrimps (Huchette et al., 2000; Bratvold and Browdy 2001; Richard et al., 2009; Zhang, 2011; Zhang et al., 2014). Autotrophic microalgae and zooplankton present in periphyton of substrate based methods gives in situ food as microalgae components viz, diatoms, ciliates, flagellates, copepods and nematodes for rearing organism (Arnold et al., 2005; Abreu et al., 2007; Fernandes da Silva et al., 2008; AudeloNaranjo et al., 2010). According to Burford et al., (2004) epiphytes offering carbon and nitrogen (39-53\%) to shrimp as they can be easily utilized by shrimp. In intensive cultures, substrates provide an extra surface area to the shrimp, which can decrease the competition for space and cannibalism 
(Abdussamad and Thampy, 1994). The bottom living animals like shrimps are constrained to two dimensional space than three-dimensional space (Kumlu et al., 2001; Otoshi et al., 2006) and have been reflects that the artificial substrates increase the space for living (Tidwell et al., 1999; Arnold et al.,
2005; 2006; Zarain-Herzberg et al., 2006). Addition of vertical substrate into shrimp culture environment helps in removal of suspended solids which can significantly reduce the organic pollutants load (Langis et al., 1988; Hargreaves, 1998; Ramesh et al., 1999).

Table.1 Studies on shrimp and prawn species as suitable candidates for biofloc culture systems

\begin{tabular}{|l|l|l|}
\hline SL.No & Species & Reference \\
\hline 1 & Litopenaeus vannamei & $\begin{array}{l}\text { Buford } \text { et al., 2004; Wasielesky et al., 2006; Samocha } \text { et } \\
\text { al., 2007; Ju } \text { et al., 2008a; Kuhn } \\
\text { et al., 2008, 2010; Krummenauer } \text { et al., 2011; Emernciano } \\
\text { et al., 2012; Bauer } \text { et al., 2012; Maica } \text { et al., 2012; Ekasari } \\
\text { et al., 2014; Luis-Villaseñor } \text { et al., 2015; Raj Kumar } \text { et al., } \\
\text { 2015; M. H. Khanjani } \text { et al., 2016. }\end{array}$ \\
\hline 2 & Avnimelech and Mokady, 1988; Panjaitan, 2004. \\
\hline 3 & Penaeus monodon & Emernciano et al., 2009. \\
\hline 4 & Penaeus setiferus & Emernciano et al., 2011a. \\
\hline 5 & Penaeus stylieus paulensis & Emernciano et al., 2011b. \\
\hline 6 & Farfantepenaeus brasiensis & Emernciano et al., 2012. \\
\hline 7 & Fenneropenaeus indicus & Effendy et al., 2016. \\
\hline
\end{tabular}

Table.2 Proximate analysis of Biofloc particles in different studies

\begin{tabular}{|l|c|c|c|c|l|}
\hline $\begin{array}{l}\text { Crude } \\
\text { protein } \%\end{array}$ & $\begin{array}{c}\text { Carbohydrate } \\
\text { \% }\end{array}$ & Lipids\% & $\begin{array}{c}\text { Crude } \\
\text { fiber\% }\end{array}$ & Ash\% & Reference \\
\hline $\mathbf{4 3 . 0 0}$ & - & 12.5 & - & 26.5 & $\begin{array}{l}\text { McIntosh } \text { et } \\
\text { al., } 2000\end{array}$ \\
\hline $\mathbf{3 1 . 2}$ & - & 2.6 & - & 28.2 & $\begin{array}{l}\text { Tacon } \text { et al., } \\
2002\end{array}$ \\
\hline $\mathbf{1 2 . 0 - 4 2 . 0}$ & - & $2.0-8.0$ & - & $22.0-46.0$ & $\begin{array}{l}\text { Soares } \text { et } \\
\text { al., } 2004\end{array}$ \\
\hline $\mathbf{3 1 . 1}$ & 23.6 & 0.5 & - & 44.8 & $\begin{array}{l}\text { Wasielesky } \\
\text { et al., } 2006\end{array}$ \\
\hline $\mathbf{2 6 . 0 - 4 1 . 9}$ & - & $1.2-2.3$ & - & $18.3-40.7$ & $\begin{array}{l}\text { Ju } \text { et al. } \\
2008 \text { a }\end{array}$ \\
\hline $\mathbf{3 0 . 4}$ & - & 1.9 & 12.4 & 38.9 & $\begin{array}{l}\text { Ju } \text { et al., } \\
2008\end{array}$ \\
\hline $\mathbf{4 9 . 0}$ & 36.4 & 1.13 & 12.6 & 13.4 & $\begin{array}{l}\text { Kuhn } \text { et al., } \\
2009\end{array}$ \\
\hline $\mathbf{3 8 . 8}$ & 25.3 & $<0.1$ & 16.2 & 24.7 & $\begin{array}{l}\text { Kuhn } \text { et al., } \\
2010\end{array}$ \\
\hline $\mathbf{2 8 . 8 - 4 3 . 1}$ & - & $2.1-3.6$ & $8.7-10.4$ & $22.1-42.9$ & $\begin{array}{l}\text { Maica } \text { et al., } \\
2012\end{array}$ \\
\hline
\end{tabular}


depends on the type of substrate and submersion time. Ledger and Hidrew (1998) recorded $2-3 \%$ protein, $0.04-0.29 \%$ lipid, and $29-33 \%$ carbohydrate in periphyton developed on stones. Azim et al., (2002) recorded that more protein from bamboo (32\%) followed by kanchi $(30 \%)$ and jute stick (13\%). Keshavanath et al., (2004) recorded $19.27-35.56 \%$ of protein in periphyton produced on bamboo. Becker (2007) reported $35-63 \%$ of protein, $10-57 \%$ of lipid and $2-22 \%$ of fat and some algae.

\section{Water Quality in Substrate Systems}

Periphyton on immersed substrate plays a major role in maintaining water quality in rearing ponds. Algae on substrate increase nitrification process and keep low levels of TAN and nitrite in water (Ramesh et al., 1999; Thompson et al., 2002; Khatoon et al., 2009). Artificial substrate can reduce turbidity level of water and sufficient plankton in water (Asaduzzaman et al., 2008; 2009a). Drenner et al., (1997) used fish and periphyton for removing of nutrients from the water. Azim et al., (2001) reported that suspended solids in water were caught on the substrate, could reduce ammonia and nitrate, produce oxygen, breaking down organic matter and enhance nitrification process. Periphyton present on the substrates can besides assimilating ammonia and nitrite, can also maintain optimum dissolved oxygen level, maintain $\mathrm{pH}$ of the water (Azim et al., 2002; Dodds, 2003; Bender et al., 2004; Schveitzer et al., 2013). Arnold et al., (2006) evaluated water quality parameters on weekly basis in rearing $P$. Monodon (PL15) for 56 days at two stocking densities $\left(1000 / \mathrm{m}^{-3} \& 2000 / \mathrm{m}^{-3}\right)$ with artificial substrates and without artificial substrates. Weekly reports shown that there is no significantly different $(\mathrm{P}>0.05)$ in temperature, dissolved oxygen and $\mathrm{pH}$ among all tanks. The mean concentrations recorded by them for TAN, nitrite and nitrate with and without artificial substrates were $0.39 \pm 0.17$ ppm and $0.86 \pm 0.15 \mathrm{ppm} ; 0.62 \pm 0.09 \mathrm{ppm}$ and $0.99 \pm 0.34 \mathrm{ppm}$ and $1.44 \pm 0.09 \mathrm{ppm}$ and $0.48 \pm 0.13 \mathrm{ppm}$ respectively. Zhang et al., (2016) recorded significantly lower mean $(\mathrm{P}<$ $0.05)$ values of nitrite and nitrate in substrate based systems than the control in L. vannamei rearing water. However, no significant difference $(\mathrm{P}<0.05)$ in mean values of TAN was observed between control and substrate groups.

\section{Growth of shrimp in SBT Systems}

The production output of P.monodon juveniles both in terms of growth and survival was significantly increased $(\mathrm{P}<0.05)$ by keeping submerged substrates (Arnold et al., 2006). Ballester et al., (2007) reported higher $(\mathrm{P}<0.05)$ final weight, survival and biomass in pink shrimp, Farfantepenaeus paulensis cultured in cages with polyethylene screen as substrates than that in cages without substrates. Uddin et al., (2007) reported that $O$. niloticus (GIFT) in polyculture with the freshwater prawn (Macrobrachium rosenbergii) showed significantly higher growth, survival and yield of both GIFT and freshwater prawn in ponds with bamboo substrates than in the control ponds. Zhang et al., (2010) reported significantly increased (P $<0.05)$ weight gain, survival and yield in $L$. vannamei with increase in number of substrates. Presence of substrates in the culturing systems has better growth of vannamei (Zhang, 2011). Similarly, Zhang et al., (2014) has showed significantly higher (P $<0.05)$ growth and survival of vannamei juveniles in substrate (bolting silk net) based ponds than that in control pond without artificial substrate under winter indoor condition.

\section{Immune Response of Shrimp in SBT System}

Studies by Zhang et al., (2010) observed significantly decreased $(\mathrm{P}<0.05)$ activity of 
non-specific immune parameters like phenoloxidase, antibacterial activity, lysozyme activity, peroxidase and hemolysin of L. vannamei juveniles reared in PVC aquaria with polypropylene fabrics screen substrates than those of control group. With an increasing substrates nos, the activity of these parameters were reduced, suggesting that submerged substrates can mitigate the negative impact of the more stocking density through providing enough living space for shrimp. The protein content of L. vannamei in both haemolymph and muscle, cultured in 1000 lit capacity cylindrical polyethylene tanks with Aquamats was more than that of control, due to the higher availability (and diversity) of the periphyton (Audelo-Naranjo et al., 2012).

\section{Periphyton Production in SBT Systems}

The production of periphyton on immersed substrates is manipulated by different factors like accessibility of nutrients in the water, availability of light, depth of water, type of substrates etc. (Hay, 1991; Konan-Brou and Guiral, 1994; Keshavanath et al., 2001). Nature and type of substrate plays a major role on periphyton development, ash free dry matter, pigments and algal colonisation on the substrate (Anderson and Underwood, 1994; Keshavanath et al., 2001; Azim et al., 2001; Danilov and Ekelund, 2001). The high periphyton biomass [dry matter (DM) and ash free dry matter (AFDM)] was noticed on bamboo substrate than jute stick, paddy straw and bagasse reported by (Keshavanath et al., 2001; Rai et al., 2008). '. In marine environment the mean DM and AFDM recorded on substrates is $8.8 \mathrm{mg} \mathrm{cm}^{-2}$ and 4.5 $\mathrm{mg} \mathrm{cm}^{-2}$ on mosquito screen after 30 days, however, 10 out of 13 experiments in freshwaters recorded below $4.5 \mathrm{mg} \mathrm{cm}^{-2}$ of $\mathrm{DM}$ and below $1 \mathrm{mg} \mathrm{cm}^{-2}$ of AFDM (Azim et al., 2004; Richard et al., 2009).
In conclusion, Biofloc technology (BFT) and periphyton based culture systems are alternative rearing systems to the existing intensive systems to make shrimp farming less cost effective and economically viable, environmentally sustainable. These systems are zero water exchange systems, so they can reduce water usage and effluent discharges and improve biosecurity. Bioflocs and biofilm (periphyton) are having complex mixture of substances such as bacteria, filamentous microalgae, protozoans, rotifers, worms and nonliving components all these materials are used by the shrimp as natural food. These systems can play a major role in sustainable aquaculture via good water quality and decrease in feed requirement, enhance immune response of shrimp and higher yield to achieve more profit in shrimp farming.

\section{Acknowledgement}

The authors acknowledge to the authorities of Sri Vekateswara Veterinary University (SVVU), Andhra Pradesh, India for the fund support in the execution of post graduate (MFSc) research work of the first author. We express our honest gratitude to Hon'ble Vice Chancellor Dr. Y. Haribabu and the Dean of fisheries faculty Dr. T.V. Ramana, SVVU for their kind support extended during the study period. The first author is also highly thankful to SVVU authorities for providing fellowship during her MFSc (Aqutic Animal Health management) study at College of Fishery Science, Muthukur, Andhra Pradesh, India.

\section{References}

Abdussamad, E.M and Thampy, D.M (1994). Cannibalism in the tiger shrimp Penaeus monodon Fabricius in nursery rearing phase. Aqua 9 (1): 67-75.

Abreu, P.C., Ballester, E.L.C., Odebrecht, C., Wasielesky Jr. W., Cavalli, R.O., Granéli, W and Anésio, A.M (2007). Importance of biofilm as food source for shrimp (Farfantepenaeus paulensis) evaluated by stable isotopes (d13C 
and d15N). Exp Mar Bio and Ecol (347): 88-96. Ahmad. I.H., A.K. Verma, A.M., Babitha Rani, G., Rathore, Neelam Saharan and Adnan Hussain Gora (2016). Growth, non-specific immunity and disease resistance of Labeo rohita against Aeromonas hydrophila in biofloc systems using different carbon sources. Aqua Res, DOI. $188 \cdot 10.1016$.

Anand P.S.S., Kohli M.P.S., Kumar, S., Sundaray J.K., Dam Roy S., Venkateshwarlu G., Sinha A and Pailan G.H (2014). Effect of dietary supplementation of biofloc on growth performance and digestive enzyme activities in Penaeus monodon. Aqua (418): 108-115.

Anand, (2012). Effects of dietary supplementation by periphyton biomass and biofloc on growth and immuno-physiological aspects of juvenile penaeus monodon fabricius (1798), M.F.Sc, Thesis, submitted to CIFE, Mumbai.

Anderson, M.J and Underwood, A.J (1994). Effects of substratum on the recruitment and development of an intertidal estuarine fouling assemblage. Exp Mar Bio and Eco (184): 217236.

Anguilera-Rivera, D., Prieto-Davo, A., Escslante, K., Chavez, C., Cuzon, G and Gaxiola G (2014). Probiotic effect of floc on vibrios in the pacific white shrimp. Aqua (283): 89-94.

Anusha, S (2017). Effect of biofloc technology on growth and immune response of Nile tilapia, oreochromis niloticus. Thesis submitted to SVVU, Tirupathi.

Arnold S.J., Sellars M.J., Crocos P.J and Coman G.J (2006). Intensive production of juvenile tiger shrimp Penaeus monodon: an evaluation of stocking density and artificial substrates. Aqua (261): 890-896.

Arnold, S.J., Sellars, M.J., Crocos, P.J., Coman, G.J (2005). Response of juvenile brown tiger shrimp (Penaeus esculentus) to intensive culture conditions in a flow through tank system with three-dimensional artificial substrate. Aqua (246): 231-238.

Asaduzzaman, M., Wahab, M., Verdegem, M.C.J., Huque, S., Salam, M and Azim, M.E (2008). $\mathrm{C} / \mathrm{N}$ ratio control and substrate addition for periphyton development jointly enhance freshwater prawn Macrobrachium rosenbergii production in ponds. Aqua (280): 117-123.

Asaduzzaman, M., Wahab, M.A., Verdegem, M.C.J., Mondal, M.N and Azim, M.E (2009a). Effects of stocking density of freshwater prawn Macrobrachium rosenbergii and addition of different levels of tilapia Oreochromis niloticus on production in $\mathrm{C} / \mathrm{N}$ controlled periphyton based system. Aqua (286): 72-79.

Audelo- Naranjo, J. G., Martínez- Córdova, L. R., Voltolina, D. and Gómez- Jiménez, S. (2011). Water quality, production parameters and nutritional condition of Litopenaeus vannamei (Boone, 1931) grown intensively in zero water exchange mesocosms with artificial substrates. Aqua res, 42 (9), 1371-1377.

Audelo-Naranjo, J.M., Martinez-Cordova, L.R and Voltolina, D (2010). Nitrogen budget in intensive cultures of Litopenaeus vannamei in mesocosms, with zero water exchange and artificial substrates. Rev de Biol Mari y Ocea (45): 519-524.

Avnimelech Y and Mokady S (1988). Protein biosynthesis in circulated fishponds In: Pullin RSV, Bhukaswan T, Tonguthai K, Maclean JL (edn) ICLARM, $2^{\text {nd }}$ international symposium on tilapia. Aqua, 16-20.

Avnimelech, Y (1999). Carbon/nitrogen ratio as a control element in aquaculture systems. Aqua (176): 227-235.

Avnimelech, Y (2012). Biofloc technology-a practical guide book, $2^{\text {nd }}$ ed. Wol Aqua Soc, Baton Rouge (48): 189.

Avnimelech, Y and Kochba, M (2009). Evaluation of nitrogen uptake and excretion by tilapia in biofloc tanks, using $15 \mathrm{~N}$ tracing. Aqua (287): 163-168.

Azim M.E and Little D.C (2008). The biofloc technology (BFT) in indoor tanks: water quality, biofloc composition, and growth and welfare of Nile tilapia (Oreochromis niloticus). Aqua (283): 29-35.

Azim M.E. and Wahab M.A (2005). Periphytonbased pond polyculture. In: Periphyton Ecology, exploitation and management. $C A B I$ Pub, Wallingford, 207-222.

Azim M.E., Verdegem M.C.J., Khatoon H., Wahab M.A., Van Dam A.A and Beveridge M.C.M (2002). A comparison of fertilization, feeding and three periphyton substrates for increasing fish production in freshwater pond aquaculture in Bangladesh. Aqua (212): 227-243.

Azim M.E., Wahab A.A., Van dan, Beveridge M.C.M., Milstein A and Verdegem M.C.J (2001). Optimization of fertilization rate for maximizing periphyton production on artificial substrates and the implications for periphyton base aquaculture. Aqua Res (32): 749-760.

Azim, M.E., Wahab, M.A., Biswas, P.K., Asaeda, 
T., Fu jino, T., Verdegem, M.C.J., (2004). The effect of periphyton substrate density on production in freshwater polyculture ponds. Aqua (232): 441-453.

Bachere, E (2000). Shrimp immunity and disease control. Aqua (191): 3-11.

Ballester, E.L.C., Abreu, P.C., Cavalli, R.O., Emerenciano, M. Abreu, L and Wasielesky, W (2010). Effect of practical diets with different protein levels on the performance of Farfantepenaeus paulensis juveniles nursed in a zero exchange suspended microbial flocs intensive system. Aqua Nut (16): 163-172.

Baloi M., Arantes R and Schveitzer R (2013). Performance of Pacific White Shrimp Litopenaeus vannamei raised in biofloc systems with varying levels of light exposure. Aqua Eng (52): 39-44.

Bauer W., Prentice-Hernandez C and Tesser M.B (2012). Substitutions of fishmeal with microbial floc meal and soy protein concentrate in diets for the Pacific White Shrimp Litopenaeus vannamei. Aqua (342): 112-116.

Becker E.W (2007). Microalgae as a source of protein. Bio Adv (25): 207-210.

Bender J., Lee R., Sheppard M., Brinkley K., Philips P., Yeboah Y and Wah R.C (2004). A waste effluent treatment system based on microbial mats for black sea bass Centropristis striata recycled-water mariculture. Aqua Engi (31): 73-82.

Bicknell, I and Dalmo, R.A (2005). The use of immunostimulants in fish larval aquaculture. Fish and shellfish imm (19): 457-472.

Bratvold, D and Browdy, C.L (2001). Effects of sand sediment and vertical surface (AquaMats ${ }^{\mathrm{TM}}$ ) on production, water quality and microbial ecology in an intensive Litopenaeus vannamei culture system. Aquaculture (195): 81-94.

Bu X., Du X., Zhou W and Zhao X., Wang J (2008). Molecular cloning, recombinant expression, and characterization of lysozyme from japonic shrimp Fenneropenaeus chinensis. Chin J of Bio (24): 723-732.

Burford M.A., Thompson P.J and McIntosh R.P (2004). The contribution of flocculated material to shrimp (Litopenaeus vannamei) nutrition in a high-intensity, zero-exchange system. Aqua (232): 525-537.

Burford, M.A., Thompson, P.J., McIntosh, R.P., Bauman, R.H and Pearson, D.C (2003). Nutrient and microbial dynamics in high- intensity, zero water exchange shrimp ponds in Belize. Aqua (219): 393-411.

Chamberiain, G.W and Hopkins, S.J (1994). Reducing water use and feed cost in intensive ponds. W Aqua (25): 29-32.

Chen, J.C and Cheng, S.Y (1995). Haemolymph oxygen content, oxyhemocyanin, protein levels and ammonia excretion in the shrimp penaeus monodon exposed to ambient nitrite. $\mathrm{J}$ of com phy B: Bio, Sys and Env Phy (164): 530-535.

Chen, J-C, Chen, Yong-Chin Lin, Su-Tuen Ten and Chein-Lun-Huang (2015). White shrimp Litopenaeus vannamei that have received Gracilaria tenuistipitata extract show early recovery of immune parameters after ammonia stressing. Mar drug (13): 3606-3624.

Chisholm, J.R.S and Smith, V.J (1995). Comparison of antibacterial activity in the haemocytes of different crustacean species. Com Bio and Phy, 110 (A): 39-45.

Chiu, C.H., Guru, Y.K. Lui, C.H. Pan, T.M and Cheng, W (2007). Immune responses and gene expression in white shrimp, Litopenaeus vannamei, induced by Lactobacillus plantarum. Fish and Shellfish Immu (23): 364-377.

Chu, C.P and Lee, D.J (2004). Multistage structure of biological flocs. Che Eng Sci (59): 18751883.

Colvin, L.B and Brand, C.W (1977). The protein requirement of penaeid shrimp at various life cycle stages in controlled environment systems. J of W Mari Soc (8): 821-840.

Cordova Luis R. Martinez and Emilio Pena-Messina (2005). Biofloc communities and feeding habits of Litopenaeus vannamei and Litopenaeus stylirostris in monoculture and polyculture semi-intensive ponds. Aqua Res 36 (11): 10751084.

Coyle, S.D., Alston, E.D and Sampaio, C.M.S (2010). Nursery systems and management in fresh water prawns. Biology and farming. Blc Sci, Oxford, UK, 108-126.

Crab, R., Avnimelech, Y., Defoirdt, T., Bossier, P and Verstraete, W (2007). Nitrogen removal techniques in aquaculture for a sustainable production. Aqua (270): 1-14.

Crab, R., Chielens B., Wille M., Bossier P and Verstraete W (2010). The effect of different carbon sources on the nutritional value of bioflocs, a feed for Macrobrachium rosenbergii postlarvae. Aqua Res (41): 559-567.

Crab, R., Defoirdt T., Bossier P and Verstraete W (2012). Biofloc technology in aquaculture: 
beneficial effects and future challenges. Aqua (357): 351-356.

Danilov, R.A and Ekelund, N.G (2001). Comparison of usefulness of three types of artificial substrata (glass, wood and plastic) when studying settlement patterns of periphyton in lakes of different trophic status. Mic Met (45): 167-170.

De Schryver, P.D., R. Crab, T., Defoirdt, N., Boon and W. Verstraete (2008). The basics of bioflocs technology: The added value for aquaculture. Aqua (277): 125-137.

Defoirdt, T., Halet, D., Vervaeren, H., Boon, N., Van de Wiele, T., Sorgeloos, P., Bossier, P and Verstraete, W (2007). The bacterial storage compound poly-â-hydroxybutyrate protects Artemia franciscana from pathogenic Vibrio campbellii. Envi Micr 9 (2): 445-452.

Depledge, M.H and Bjeregaard, J (1989). Haemolymph protein composition and copper levels in decapods crustaceans heigol. Meeresuntes (43): 207-233.

Devaraja, T.N., Otta, S.K., Karunasagar, I., Tauro, P and Karunasagar, I (1998). Immunostimulation of shrimp through oral administration of Vibrio bacterin and yeast glucan. In: Advances in shrimp biotechnology. (ed. Flegel, T.W). Na C for Gen Eng and Bio, Bangkok, 167-170.

Dodds W.K (2003). The role of periphyton in phosphorus retention in shallow freshwater aquatic systems. J of Phy (39): 840-849.

Drenner R.W, Day D.J, Basham S.J, Smith J.D and Jensen S.I (1997). Ecological water treatment system for removal of phosphorous and nitrogen from polluted water. Ecol Appl (7): 381-390.

Ebeling J.M., Timmons M.B and Bisogni J.J (2006). Engineering analysis of the stoichiometry of photoautotrophic, autotrophic, and heterotrophic removal of ammonia-nitrogen in aquaculture systems. Aqua (257): 346-358.

Effendy, Samy A.l Deen and Sambhu Chithambaran (2016). Semi Intensive and Semi Biofloc Methods for the Culture of Indian White Prawn, Fenneropenaeus indicus in High-density Polyethylene Liner Ponds. Hy Bio (23): 106110.

Ekasari J., Muhammad Hanif Azhar, Enang H., Surawidjaja, Sri Nuryati, Peter De Schryver and Peter Bossier (2014). Immune response and disease resistance of shrimp fed biofloc grown on different carbon sources. Fish and Shellfish $\operatorname{Imm}(41)$ : 332-339
Emerenciano M., Ballester E.L.C, Cavalli R.O and Wasielesky W (2012). Biofloc technology application as a food source in a limited water exchange nursery system for Pink Shrimp Farfantepenaeus brasiliensis (Latreille, 1817). Aqua Res (43): 447-457.

Emerenciano M., Ballester E.L.C, Cavalli R.O and Wasielesky W (2011b). Effect of biofloc technology (BFT) on the early postlarval stage of Pink Shrimp Farfantepenaeus paulensis: growth performance, floc composition and salinity stress tolerance. Aqua Int (19): 891901.

Emerenciano M., Cuzon G., Goguenheim J., Gaxiola $G$ and Aquacop (2011a). Floc contribution on spawning performance of blue shrimp Litopenaeus stylirostris. Aqua res (44): 75-85.

Emerenciano M., Gaxiola G and Cuzon G (2013). Biofloc Technology (BFT): A review for aquaculture application and animal food industry. In: Matovic M.D (ed) Biomass now cultivation and utilization. InTech, Rijeka, 301328.

Emerenciano, M., vainatea, L., Galvez, A.G. Shuler, A., Stokes, A., Venero, J., Harveman, J., Richardson, J., Thaomsan, B and Leffler, J (2009). Effect of two different diets fish meal based and organic plant based diets in Litopenaeus setiferus earlier post-larvae culture under biofloc, green-water and clean-water condition. Abstract of W Aqua Soc Meeting, Verscruz, Mexico.

Fernandes da Silva, C., Ballester, E., Monserrat, J., Geracitano, L., Wasielesky J.W and Abreu, P.C (2008). Contribution of microorganisms to the biofilm nutritional quality: protein and lipid contents. Aqua Nut (14): 507-514.

Flegel, T.W (1997). Major viral diseases of the black tiger prawn (Penaeus monodon) in Thailand. W $\mathrm{J}$ of Mi and Bio (13): 433-442.

Focken, U., Groth, A., Coloso, R.M and Becker, K (1998). Contribution of natural food and supplemental feed to the gut content of Penaeus monodon fabricius in a semi-intensive pond system in the Philippines. Aqua (164): 105-116.

Fontenot, Q., Bonvillain, C., Kilgen, $\mathrm{M}$ and Boopathy, R (2007). Effects of temperature, salinity, and carbon: nitrogen ratio on sequencing batch reactor treating shrimp aquaculture wastewater. Bio Tec (98): 17001703.

Gao, L., Shan, H.W., Zhang, T.W., Bao, W.Y and Ma, S (2012). Effects of carbohydrate addition 
on Litopenaeus vannamei intensive culture in a zero-water exchange system. Aqua (342-343): 89-96.

Hall, M.R and Van Ham, E.H (1998). The effects of different types of stress on blood glucose in the giant tiger prawn Penaeus monodon. W Aqua Soc (29): 290-299.

Hargreaves, J.A (1998). Nitrogen biogeochemistry of aquaculture ponds. Aqua (166): 181-212.

Hargreaves, J.A (2006). Photosynthetic suspendedgrowth systems in aquaculture. Aqua Eng (34): 344-363.

Hargreaves, J.A (2013). Biofloc production systems for aquaculture. Southern Regional Aqua Ce Publ, 4503.

Hari B., Kurup B.M., Varghese J.T., Schrama J.W and Verdegem M.C.J (2006). The effect of carbohydrate addition on water quality and the nitrogen budget in extensive shrimp culture systems. Aqua (252): 248-263.

Hari, B., Kurup, B.M., Varghese, J.T., Schrama, J.W and Verdegem, M.C.J (2004). Effects of carbohydrate addition on production in extensive shrimp culture systems. Aqua (241): 179-194.

Hay, M.E (1991). Fish-seaweed interactions on coral substrates: Effects of herbivorous fishes and adaptations of their prey. In: The Ecology of fishes on coral substrates. (ed. Sale, P.F). Aca Pr, London, 96-119.

Hikima S., Hikima J., Rojitinnakorn J., Hirono I and Aoki T (2003). Characterization and function of kurma shrimp lysozyme processing lytic activity against Vibrio species. Gene (316): 187-195.

Huchette S.M.H., Beveridge M.C.M., Baird D.J and Ireland, M (2000). The impacts of grazing by tilapias (Oreochromis niloticus.) on periphyton communities growing on artificial substrate in cages. Aqua (186): 45-60.

Jang, I.K., Pang, Z., Yu, J., Kim, S.K., Seo, H.C and Cho, Y.R (2011). Selectively enhanced expression of prophenoloxidase activity enzyme 1 (PPAE1) at a bacteria clearance site in the white shrimp, Litopenaeus vannamei. BMC imm (12): 70-80.

Ji. P.F., Yao, C.L and Wang, Z.Y (2009). Immune response and gene expression in shrimp (Litopenaeus vannamei) haemocytes and hepatopancreas against some pathogenassociated molecular patterns. Fish and Shellfish Imm (27): 563-570.

Ju Z.Y., Forster I.P., Conquest L., Dominy W., Kuo
W.C and David Horgen F (2008a). Determination of microbial community structures of shrimp floc cultures by biomarkers and analysis of floc amino acid profiles. Aqua Res (39): 118-133.

Ju, Z.Y., Forster, I.P., Conquest, L., Dominy, W (2008b). Enhanced growth effects on shrimp (Litopenaeus vannamei) from inclusion of whole shrimp floc or floc fractions to a formulated diet. Aqua Nut (14): 533-543.

Kent M., Craig L., Browdy and John W. Leffler (2011). Consumption and digestion of suspended microbes by juveniles pacific white shrimp Litopenaeus vannamei. Aqua (319): 363-368.

Keshavanath P., Gangadhar B., Ramesh T.J., Van Dam A.A, Beveridge M.C.M and Verdegem (2004). Effect of bamboo substrate and supplemental feeding on growth and production of hybrid red tilapia fingerlings (Oreochromis mossambicus - Oreochromis niloticus). Aqua (235): 303-314.

Keshavanath, P., Gangadhar, B., Ramesh, T.J., Van Rooij, J.M., Beveridge, M.C.M., Baird, D.J., Verdegem, M.C.J and van Dam, A.A (2001). Use of artificial substrates to enhance production of freshwater herbivorous fish in pond culture. Aqua Research (32): 189-197.

Khatoon, H., Banerjee, S., Yusoff, F. M and Shariff, M (2009). Evaluation of indigenous marine periphytic Amphora, Navicula and Cymbella grown on substrate as feed supplement in Penaeus monodon. Aqua Nut (15): 186-193.

Kim, S.K., Pang, Z., Seo, H.-C., Cho, Y.-R., Samocha, T and Jang, I.K (2014). Effect of bioflocs on growth and immune activity of Pacific white shrimp, Litopenaeus vannamei postlarvae. Aqua Res (45): 362-371.

Konan-Brou, A.A and Guiral, D (1994) Available algal biomass in tropical brackish water artificial habitats. Aqua (119): 175-190.

Krummenauer D., Peixoto S., Cavalli R.O., Poersch L.H and Wasielesky W (2011). Superintensive culture of white shrimp, Litopenaeus vannamei in a biofloc technology system in southern Brazil at different stocking densities. W Aqua Soc (42): 726-733.

Kuhn D.D., Boardman G.D., Craig S.R., Flick G.J and Mclean E (2008). Use of microbial flocs generated from tilapia effluent as a nutritional supplement for shrimp, Litopenaeus vannamei, in recirculating aquaculture systems. W Aqua Soc (39): 72-82. 
Kuhn D.D., Lawrence A.L., Boardman G.D., Patnaik, S., Marsh, L and Flick, G.J (2010). Evaluation of two types of bioflocs derived from biological treatment of fish effluent as feed ingredients for Pacific White Shrimp, Litopenaeus vannamei. Aqua (303): 28-33.

Kumar. S., Anand P.S.S., Debases D., Ghoshal, T.K and Jithendran, K.P (2015). Effects of Biofloc and Mat Based Substrates on Microbial Composition, Growth Performance and Immune Responses in Black Tiger Shrimp Penaeus monodon in the $10^{\text {th }}$ Indian fisheries and aquaculture forum (10IFAF) NBFGRR, Lucknow, India (12-15).

Kumar. S., Panantharayil S Shyne Anand, Debasis De, Ashutosh D Deo, Tapas K Ghoshal, Jitendra K Sundaray, Alphis G Ponniah and Jithendran. K.P (2015). Effects of biofloc under different carbon sources and protein levels on water quality, growth performance and immune responses in black tiger shrimp Penaeus monodon (Fabricius, 1978). Aqua. Res. 1-15.

Kumlu, M., Eroldogan, O.T and Saglamtimur, B (2001). The effects of salinity and added substrates on growth and survival of Metapenaeus monoceros (Decapoda: Penaeidae) post-larvae. Aqua (196): 177-188.

Langis R., Proulx D., de la Noeue J and Couture P (1988). Effects of a bacterial biofilm on intensive Daphnia culture. Aqua Eng (7): 21-38.

Lara-Flores, M., Olvera-Novoa, M.A., GuzmanMendez, B.E and Lopez-Madrid, W (2003). Use of the bacteria Streptococcus faecium and Lactobacillus acidophilus, and the yeast Saccharomyces cerevisiae as growth promoters in Nile tilapia (Oreochromis niloticus). Aqua (216): 193-201.

Ledger M.E and Hildrew A.G (1998). Temporal and spatial variation in the epilithic biofilm of an acid stream. Fre Bio (40): 655-670.

Lee, S.Y and Soderhall, K (2001). Characterization of a pattern recognition protein, a masqueradelike protein, in the freshwater cray fish Pacifastacus leniusculus. Imm (166): 73197326.

Linan-Cabello, M. A., Paniagua-Michel, J and Hopkins, P.M (2002). Bioactive roles of carotenoids and retinoids in crustaceans. Aqua Nut (8): 299-309.

Lopez, N., Cuzon, G., Gaxiola, G., Taboada, G., Valenzuela, M., Pascual, C., Sanchez, A and Rosas, C (2003). Physiological, nutritional and immunological role of dietary $\beta$-1-3 glucan and ascorbic acid monophosphate in Litopenaeus vannamei juveniles. Aqua (224): 223-243.

López, T. H., Teresa Gollas-Galván, T.G. and Albores, F. (1996). Activation of the prophenoloxidase system of the brown shrimp Penaeus californiensis Holmes. Comparative Biochemistry and Physiology Part C: Pharmacology, Tox and End, 113 (1), 61-66. Lorgeril, J., Saulnier, D., Janech, M. G., Gueguen, Y., and Bachère, E. (2005). Identification of genes that are differentially expressed in hemocytes of the Pacific blue shrimp (Litopenaeus stylirostris) surviving an infection with Vibrio penaeicida. Phy Gen, (21), 174183.

Luis-Villaseñor, Domenico Voltolina, Juan M. Audelo-Naranjo, María R. Pacheco-Marges, Víctor E. Herrera-Espericueta and Emilio Romero-Beltrán (2015). Effects of biofloc promotion on water quality, growth, biomass yield and heterotrophic community in Litopenaeus vannamei (Boone, 1931) experimental intensive culture. Ita J of Ani Sci (14): 332-337.

Luo G., Gao Q and Wang C (2014). Growth, digestive activity, welfare, and partial costeffectiveness of genetically improved farmed tilapia (Oreochromis niloticus) cultured in a recirculating aquaculture system and an indoor biofloc system. Aqua (422): 1-7.

M. H. Khanjani, Mir Masoud Sajjadi, Morteza Alizadeh \& Sourinejad, I. (2016). Nursery performance of Pacific white shrimp (Litopenaeus vannamei Boone, 1931) cultivated in a biofloc system: the effect of adding different carbon sources. Aquaculture Research, $1-11$.

Mai W and Hu C (2009). Molecular cloning, 116aponicas116ts116ion, expression and antibacterial analysis of a lysozyme homologue from Fenneropenaeus merguuiensis .Mol Bio Re (36): 1587-1595.

Maicá P.F., Borba M.R and Wasielesky W (2012). Effect of low salinity on microbial floc composition and performance of Litopenaeus vannamei (Boone) juveniles reared in a zerowater-exchange super-intensive system. Aqua Res (43): 361-370.

Manan, H., Zhong Moh, J.H., Kasan, j.k., Suratman, $\mathrm{S}$ and khwanuddin, M. (2017). Identification of biofloc microscopic composition as the natural bioremediation in zero water exchange of Pacific white shrimp, 
Penaeus vannamei, culture in closed hatchery system. Appl Water Sci, 7:2437-2446.

Martinez-Porchas and Luis, R. Martinez-Cordova (2012). World Aquaculture: environmental impacts and troubleshooting alternatives. The Scientific World Journal, Article ID 389623, 19.

McIntosh, D., Samocha, T.M., Jones, E.R., Lawrence, A.L, Mc Kee, D.A., Horowitz, S and Horowitz, A (2000). The effect of a bacterial supplement on a high density culturing of Litopenaeus vannamei with low protein diet in outdoor tank system and no water exchange. Aqua Eng (21): 215-227.

Megahed, M.E (2010). The effect of Microbial Biofloc on water quality, survival and growth of the green tiger shrimp (Penaeus Semisulcatus) fed with different crude protein levels. J of Ar Aqua Soc (5): 119-142.

Meyers, S.M and Latscha, T (1997). Carotenoid In: Advances in world aquaculture, crustacean nutrition. (eds, Louis, R and Abramo, D) W Aqua Soc, Baton Rouge, Los Angeles, 164-193.

Michaud L., Blancheton J.P., Bruni V and Piedrahita R (2006). Effect of particulate organic carbon on heterotrophic bacterial populations and nitrification efficiency in biological filters. Aqua Eng (34): 224-233.

Milstein A., Avnimelech Y., Zoran M and Joseph D (2001). Growth performance of hybrid Bass and hybrid tilapia in conventional and active suspension intensive ponds. Is $J$ of Aqua Bamidgeh (53): 147-157.

Mohamed E. Megahed (2010). The Effect of Microbial Biofloc on Water Quality, Survival and Growth of the Green Tiger Shrimp (Penaeus Semisulcatus) Fed with Different crude Protein Levels. J Ara Aqua Soc, 5(2): 119-141.

Moss, S.M., Divakaran, S and Kim B.G (2001). Stimulating effects of pond water on digestive enzyme activity in the Pacific white shrimp Litopenaeus vannamei (Boone). Aqua Res (32): 125-131.

Moss, S.M., Forster, I.P and Tacon, A.G.J (2006). Sparing effect of pond water on vitamins in shrimp diets. Aqua (258): 388-395.

Mundo S.R.R., Islas-Osuma M.A., de-la-re-Vega E., Hernandez-Lopez J., Vargs-Albores F and Yepiz-Plascencia G (2003). cDNA cloning of the lysozyme of the white shrimp Penaeus vannamei. Fish and Shellfish Im (15): 352-331.

NACA (2012). Report of the Asia Pacific emergency regional consultation on the emerging shrimp disease: early mortality syndrome (EMS/acute hepatopancreatic necrosis syndrome (AHPNS). Net of Aqua cen in Asia-Pacific (9-10).

Ninawe, A.S and Selvin, J (2009). Probiotics in shrimp aquaculture: avenues and challenges. Cri Revi in Mic (35): 43-66.

Nonwachai, T., Purivirojkul, W., Limsuwan, C., Chuchird, N., Velasco, $\mathrm{M}$ and Dhar, A.K (2010). Growth, nonspecific immune characteristics, and survival upon challenge with Vibrio harveyi in Pacific white shrimp (Litopenaeus vannamei) raised on diets containing algal meal. Fish Shellfish Imm (29): 298-304.

Otoshi, C.A., Montgomery, A.D., Matsuda, E.M and Moss, S.M (2006). Effects of artificial substrate and water source on growth of juvenile pacific white shrimp, Litopenaeus vannamei. W Aqua Soc (37): 210-213.

Panigrahi, A., Kiron, V., Satoh, S., Hirono, I., Kobayashi, T., Sugit a, H., Puangkaew, J. and Aoki, T (2007). Immune modulation and expression of cytokine genes in rainbow trout Oncorhynchus mykiss upon probiotic feeding. Del and Com Imm (31): 372-382.

Panigrahi, A., Sundaram, P., Ravicharan and C. Gopal (2014). Microbial soup-Eco based approach for shrimp culture and management. ENVIS Newsletter on Microorganisms and Environment Management (12): issue. 2

Panjaitan P (2004). Field and laboratory study of Penaeus monodon culture with zero water exchange and limited water exchange model using molasses as a carbon source. Ph.D. Thesis, Charles Darwin Univ., Darwin, NT, Australia.

Peng Y and Zhu G (2006). Biological nitrogen removal with nitrification and denitrification via nitrite pathway. Ap Mic and Bio (73): 1526.

Perazzolo L.M and Barracco M.A (1997). The prophenoloxidase activating system of the shrimp Penaeus paulensis and associated factors. Dev and Com Imm (21): 385-395.

Perazzolo, L.M., Gargioni, R., Ogliari, P and Barracco, M.A.A (2002). Evaluation of some hemato-immunological parameters in the shrimp Farfantepenaeus paulensis submitted to environmental and physiological stress. Aqua, (214): 19-33.

Peregrine-Uriate, Adrinana T., Muhlia-Almazan, 
Aldo, A., Arvizu-Flores, Gracia GomezAnduro, Teresa Gollas-Galvan, Gloria YepizPlascencia, Rogerio $\mathrm{R}$ and Sotelo-Mundo (2012). Shrimp invertebrate lysozyme i-lyz: Gene structure, molecular model and response of $c$ and $I$ lysozyme to lipopolysaccharide (LPS). Fish and Shellfish Imm (32): 230-236.

Perez- Fuentes, J.A., Perez-Rostro, C.I and Hernandez-Vergara, M.P (2013). Pond reared Malaysian prawn Macrobranchium rosenbergii with the biofloc system. Aqua (400): 105-110.

Phillips, N.W (1984). Role of different microbes and substrates as potential suppliers of specific, essential nutrients to marine detritivores. Bul of Mar Sci (35): 283-298.

Rai, S., Yi, Y., Wahab, M.A., Bart, A.N and Diana, J. S (2008). Comparison of rice straw and bamboo stick substrates in periphyton-based carp polyculture systems. Aqua Res (39): 464473.

Rajkumar, $\mathrm{M}$ and Kumaraguru vasagam, K.P (2006). Suitability of the copepod, Acartia 120 aponi as a live feed for seabass larvae (Lates calcarifer) compared to traditional live-food organisms with special emphasis on the nutritional value. Aqua (261): 649-658.

RajKumar, M., Pandey, P.K., Alagarsamy, R. A., Vennila , Vivekanand Bharti, V. and Purushothaman, C.S (2015). Effect of different biofloc system on water quality, biofloc composition and growth performance in Litopenaeus vannamei (Boone, 1931). Aqua Res: 1-13

Ray A.J., Lewis B.L., Browdy C.L and Leffler J.W (2010b). Suspended solids removal to improve shrimp (Litopenaeus vannamei) production and an evaluation of a plant-based feed in minimalexchange, superintensive culture systems. Aqua (299): 89-98.

Ray A.J., Seaborn G and Leffler J.W (2010a). Characterization of microbial communities in minimal-exchange, intensive aquaculture systems and the effects of suspended solids management. Aqua (310):130-138.

Rengpipat, S., Rukpratanporn, S., Piyatiratitivorakul, $S$ and Menasaveta, P (2000). Immunity enhancement in black tiger shrimp (Penaeus monodon) by a probiont bacterium (Bacillus S11). Aqua (191): 271-288.

Richard, M., Trottier, C., Verdegem, M.C.J and Hussenot, J.M.E (2009). Submersion time, depth, substrate type and sampling method as variation sources of marine periphyton. Aqua
(295): 209-217.

Ringo E., Jose R.E.O., Vecino L.G., Wadsworth S and Song S (2012). Use of immunostimulants and nucleotides in aquaculture: A Review. Mar Sci Res Dev (2): 1-22.

Rittmann, B.E and Mc Carty, P.L (2001). Environmental biotechnology: Principles and applications. (eds. Rittmann B.E and Mc Carty, P.L) Cen for Envi Bio. McGrraw-Hill book Co, New York, 743.

Rodriguez J and Le Moullac G (2000). State of the art of immunological tools and health control of penaeid shrimp. Aqua (191): 109-119.

Salehizadeh, H and Shojaosadati, S.A (2001). Extracellular biopolymeric flocculants: Recent trends and biotechnological importance. Bio Ad (19): 371-385.

Samocha T.M, Patnaik S., Speed M., Ali A.M., Burger J.M., Almeida R.V., Ayub Z., Harisanto M., Horowitz A and Brock D.L (2007). Use of molasses as carbon source in limited discharge nursery and grow-out systems for Litopenaeus vannamei. Aqua Eng (36): 184-191.

Schveitzer, R. Rafel Arantes, Patrica Foes S.Costodio, Carlos M. Do Espirito Santo, Luis Vinatea Arana, Walter Quadros Seiffert and Edemar Roberto Andreatta (2013). Effect of different biofloc levels on microbial activity, water quality and performance of Litopenaeus vannamei in a tank system operated with no water exchange. Aqu Eng (56): 59-70.

Senanan, W., Panutrakul, S., Barnette, P., Chavanich, S., Mantachitr, V., Tangkrock-Olan, $\mathrm{N}$ and Viyakarn, V (2009). Preliminary risk assessment of Pacific whiteleg shrimp ( $P$. vannamei) introduced to Thailand for aquaculture. Aqu A Magazine, 14 (4): 28-32.

Serfling, S.A (2006). Microbial flocs-natural treatment method supports freshwater, marine species in recirculating systems. G Aqua Ad: 34-36.

Serra. F.P, Carlos A. P. Gaona, Plínio S. Furtado, Luis H. Poersch and Wilson WasieleskyJr (2015). Use of different carbon sources for the biofloc system adopted during the nursery and grow-out culture of Litopenaeus vannamei. Aquauclture internatinal: (23): 1325-1339.

Sinha, A.K., Baruah, K. and Bossier, P (2008). Horizon Scanning: the potential use of biofloc as an anti-infective strategy in aquaculture an overview. Aqua He Inte (13): 8-10.

Smith V.J., Brown J.H and Hauton C (2003). Immunostimulation in crustaceans: does it 
really protect against infection? Fish Shellfish $\operatorname{Im}(15)$ : 71-90.

Soderhall, K and Cerenius, L (1992). Crustacean immunity. An Review of Fish Dis (2): 3-23.

Sritunyalucksana K and Soderhall K (2000). The proPO and clotting system in crustaceans. Aqua (191): 53-69.

Suita S.M (2009). O uso da Dextrose como fonte de 123 aponi no desenvolvimento de bioflocos e desempenho do camarão-branco (Litopenaeus vannamei) cultivado em sistema sem renovação de água. Dissertation, Federal University of Rio grande, Brasil.

Supamattaya, K., Kiriratnikom, S., Boonyaratpalin, $M$ and Borowitzka, L (2005). Effect of a Dunaliella extract on growth performance, health condition, immune response and disease resistance in black tiger shrimp (Penaeus monodon). Aqua (248): 207-216.

Supungul P., Klinbunga S., Pichyangkure R., Jitrapakadee S., Hirono I and Aoki T (2002). Identification of immune related genes in haemocytes of black tiger shrimp (Penaeus monodon). Ma Bio (4): 487-494.

Tacon, A., Cody, J.J., Conquest, L.D., Divakaran, S., Forster, I.P and Decamp, O.E (2002). Effect of culture system on the nutrition and growth performance of Pacific white shrimp, Litopenaeus vannamei (Boone) fed different diets. Aqua Nut (8): 121-137.

Tal Y, Watts J.E.M and Schreier S.B (2003). Characterization of the microbial community and nitrogen transformation processes associated with moving bed bioreactors in a closed recirculated mariculture system. Aqua (215): 187-202.

Thompson F.L., Abreu P.C and Wasielesky W (2002). Importance of biofilm for water quality and nourishment in intensive shrimp culture. Aqua (203): 263-278.

Tidwell, J.H., Coyle, S., Webel, C and Evans, J (1999). Effects and interactions of stocking density and added substrate on production and population structure of fresh water prawns. W Aqu So (30): 174-179.

Toledo, Bruno Correa Silva, Felipe do Nascimento Vieira, Jose Luiz Pedreira Mourino and Walter Quadros Seiffert (2014). Effects of different dietary lipid levels and fatty acids profile in the culture of white shrimp Litopenaeus vannamei (Boone) in biofloc technology: water quality, biofloc composition, growth and health. Aqua res 47 (6): 1841-1851.
Tyagi A., Khushiramani $\mathrm{R}$ and Karunasagar I (2007). Antivibrio activity of recombinant lysozyme expressed from black tiger shrimp Penaeus monodon. Aqua (272): 246-253.

Uddin M.S (2007). Mixed culture of tilapia (Oreochromis niloticus) and freshwater prawn (Macrobrachium rosenbergii) in periphytonbased ponds. Ph.D, Thesis, Wageningen University, the Netherlands. Aqua Res (37): 241-247.

Van Dam A.A., Beveridge M.C., Azim M.E and Verdegem M.C (2002). The potential of fish production based on periphyton. Re in Fish Bio and Fis, (12): 1-31.

Vargas-Albores, F., Hernandez-Lopez, J., GollasGalván, T., Montano-Perez, K., Jimenez-Vega, F and Yepiz-Plascencia, G (1998). Activation of shrimp cellular defence functions by microbial products. In: Advances in shrimp biotechnology. (ed. Flegel, T. W). National Center for Genetic Engineering and Biotechnology, Bangkok, 161-166.

Vazquez L., Alpuche J., Maldonado G., Agundis C., Pereyra-morales and Zenteno E (2009). Review: Immunity mechanisms in crustaceans. End Res (15): 179.

Vega E., Garcida-Galaz A., Diaz-Clnco M.E and Sotelo-Mundo R.R (2006). White shrimp recombinant lysozyme has antibacterial activity against gram negative bacteria: Vibrio alginolyticus, Vibrio parahaemolyticus and Vibrio cholera. Fish and Shellfish Imm (20): 405-408.

Wasielesky Wilson Jr., Heidi Atwood, A.l., Stokes and Craig L. Browdy (2006). Effect of natural production in a zero exchange suspended microbial floc based super-intensive culture system for white shrimp Litopenaeus vannamei. Aqua (258): 396-403.

Weitzel, R.L (1979). Periphyton 125aponicas125ts and applications. In: Methods and measurements of periphyton communities. (ed. Weitzel, R.L). Special Technical Publication. American Society for Testing and Materials, Philadelphia, 3-33.

Xu W.J and Pan L.Q (2013). Enhancement of immune response and antioxidant status of Litopenaeus vannamei juvenile in biofloc-based culture tanks manipulating high $\mathrm{C} / \mathrm{N}$ ratio of feed input. Aqua (412-413): 117-124.

Xu W.J and Pan L.Q (2014). Evalution of dietary pritein level on selected paramerters of immune and antioxidant systems and growth 
performance of juvenile Litopenaeus vannamei rared in zero water exchange biofloc- based culture tanks. Aqua (426): 181-188.

Xu W.J., Pan L.Q., Zhao D.H and Huang J (2012). Preliminary investigation into the contribution of bioflocs on protein nutrition of Litopenaeus vannamei fed with different dietary protein levels in zero-water exchange culture tanks. Aqua (350): 147-153.

Xu, W.J and Pan, L.Q (2012). Effects of bioflocs on growth performance, digestive enzyme activity and body composition of juvenile Litopenaeus vannamei in zero-water exchange tanks manipulating $\mathrm{C} / \mathrm{N}$ ratio in feed. Aqua (357): 147-152.

Xu, W.J., Pan, L.Q., Sun, X.H and Huang, J (2012a). Effects of bioflocs on water quality, and survival, growth and digestive enzyme activities of Litopenaeus vannamei (Boone) in zero-water exchange culture tanks. Aqua Res, doi: 10.1111/j.1365-2109.2012. 03115.x.

Xu, W.J., Pan, L.Q., Sun, X.H. and Huang, J (2013). Effects of bioflocs on water quality, and survival, growth and digestive enzyme activities of Litopenaeus vannamei (Boone) in zero-water exchange culture tanks. Aqua Res (44): 10931102.

Zarain-Herzberg, M., Campa-Cordova, A.I and Cavalli, R.O (2006). Biological viability of producing white shrimp Litopenaeus vannamei in seawater floating cages. Aqua (259): 283289.

Zhang, B (2011). Influence of the artificial substrates on the attachment behavior of Litopenaeus vannamei in the intensive culture condition. Int $\mathrm{J}$ of An and Vet Adv 3 (1): 37-43.

Zhang, B., Lin, W., Wang, Y and Xu, R (2010). Effects of artificial substrates on growth, spatial distribution and non-specific immunity factors of Litopenaeus vannamei in intensive culture. Turkish J of Fish and Aqu Sci (10): 491-497.

Zhang, J., Liangliang Chen, Hongbiao Dong, Yafei Duan, Zhuojia Li, Guoliang Wen, Jianguang
Chen, Zhenhua Feng, WenJun Xu and JianJun Xie (2016). Artificial substrates in zero-waterexchange culture system regulate the rearing performance of Pacific white shrimp Litopenaeus vannamei (Boone, 1931) under the winter indoor condition. Aqua Res (47): 91100.

Zhang, J., Liangliang Chen, Hongbiao Dong, Yafei Duan, Zhuojia Li, Guoliang Wen, Jianguang Chen, Zhenhua Feng, WenJun Xu and JianJun Xie (2014). Artificial substrates in zero-waterexchange culture system regulate the rearing performance of Pacific white shrimp Litopenaeus vannamei (Boone, 1931) under the winter indoor condition. Aqua Res, 1-10.

Zhang, J., Liangliang Chen, Hongbiao Dong, Yafei Duan, Zhuojia Li, Guoliang Wen, Jianguang Chen, Zhenhua Feng, WenJun Xu and JianJun Xie (2014). Artificial substrates in zero-waterexchange culture system regulate the rearing performance of Pacific white shrimp Litopenaeus vannamei (Boone, 1931) under the winter indoor condition. Aqua Res, 1-10.

Zhao, P., Huang, J., Wang, X.H., Song, X.L., Yang, C.H., Zhang, X.G and Wang, G.C (2012). The application of bioflocs technology in highintensive, zero exchange farming systems of Marsupenaeus japonicas. Aqua (354): 97-106.

Zhukova, N.V and Kharlamenko, V.I (1999). Sources of essential fatty acids in the marine microbial loop. Aqu Mic Eco (17): 153-157.

Zhukova, N.V and Kharlamenko, V.I (1999). Sources of essential fatty acids in the marine microbial loop. Aqu Mic Eco (17): 153-157.

Ziaei-Nejad, S., Rezaei, M.H., Takami, G.A., Lovett, D.L., Mirvaghefi, A.R and Shakouri, M (2006). The effect of Bacillus spp. Bacteria used as probiotics on digestive enzymeactivity, survival and growth in the Indian white shrimp Fenneropenaeus indicus. Aqua (252): 516-524.

\section{How to cite this article:}

Chethurajupalli Lavanya, Tambireddy Neeraja, Suresh Kummari and Meshram Supradhnya Namdeo. 2020. Microbial Based Culture Systems: For Sustainable Shrimp Production. Int.J.Curr.Microbiol.App.Sci. 9(01): 1582-1604. doi: https://doi.org/10.20546/ijcmas.2020.901.175 